Економічні науки: збірник наукових праџь Луцького національного технічного університету. Серія “Регіональна економіка". Випуск 18 (71). Редкол.: відп. ред. д.е.н., професор Л.Л. Ковальська. Луцьк: ІВВ Луиького НТУ, 2021. 278 с.

3. Porter M. Mezhdunarodnaia konkurentsyia. URL: https://f.ua/alpinapablisher/mejdunarodnaja-konkurencija-konkurentniye-preimusheestva-stran. html

4. Tkachenko D.O. Analiz osoblyvostei suchasnykh teoretychnykh kontseptsii formuvannia ta funktsionuvannia TNK. Prychornomorski ekonomichni studii. Ekonomichnyi naukovo-praktychnyi zhurnal. Vypusk 11. 2016 r. S.55-59. URL: http://bses.in.ua/journals/2016/11-2016/14.pdf [in Ukrainian].

5. Kachur A.V., Mohylko D.M. TNK ta yikh rol u suchasnykh mizhnarodnykh ekonomichnykh vidnosynakh. Ekonomika i suspilstvo. Svitove hospodarstvo i mizhnarodni ekonomichni vidnosyny. Elektronnyi zhurnal. Vypusk №19. 2018. S.55-62. URL: http://economyandsociety.in.ua/journals/19_ukr/9.pdf. / [in Ukrainian].

DOI: https://doi.org/10.36910/2707-6296-2021-18(71)-3

УДК 332.1

Дзюбинська О.В., к.е.н., ст. викладач

Дзюбинський А.В., к.е.н., доцент

Голодюк Г.І., к.т.н., доцент

Луцький національний технічний університет

\title{
ІМПОРТ ВІДХОДІВ В УКРАЇНІ: ПРОБЛЕМА ЧИ ПЕРСПЕКТИВИ
}

В статті розглянуто стан справ у сфері переробки твердих побутових відходів (ТПВ). Відзначається, що не дивлячись на величезні щорічні додаткові обсяги сміття на полігонах, українські переробні підприємства вимушені імпортувати сировину. Висновок з цієї ситуації один: наші ТПВ низької якості та не можуть повноцінно бути використані у переробці. Тобто імпорт $є$ вимушеним. Сдиним виходом 3 ситуації ми бачимо у якомога більшому охоплені регіонів України роздільним збором твердих побутових відходів.

Ключові слова: імпорт, відходи, сміття, регіон, роздільний збір.

\section{Dziubynska O., Dziubynskyi A.,Golodyuk G. WASTE IMPORTS IN UKRAINE: PROBLEM OR PROSPECTS}

Solid waste recycling is a rather complex process that requires not only significant financial investments, but also deal it desire. 
Економічні науки: збірник наукових праць Луцького національного технічного університету. Серія “Регіональна економіка". Випуск 18 (71). Редкол.: відп. ред. д.е.н., професор Л.Л. Ковальська. Луиьк: ІВВ Луиького НТУ, 2021. 278 с.

An example of rational waste management is Sweden, where not only the own garbage almost completely recycled, but it is also imported. It turns out that recycling can be a business, and tons of waste at Ukrainian landfills and dumps - a cheap resource. Moreover, the current energy crisis in Europe should give impetus to the development of the municipal solid waste management sector, given the possibility of creating additional energy sources, and research in this segment is becoming particularly relevant.

Strange as it may sound, domestic solid waste recycling companies lack their own raw materials (primarily cardboard and paper, glass, polymer and plastic recycling companies). And this despite the fact that millions of tons unprocessed garbage create and will creating in the future huge problems for Ukrainians. One of the main reasons for this state of affairs, according to experts, is the lack of proper institutional support for separate waste collection, which leads to the fact, that Ukrainian waste, for the most part, is of poor quality and unsuitable for recycling. Waste import in Ukraine has a forced character. The main practice of solid waste management is their disposal, although, almost 40 percent of domestic waste amount paper, glass and polymers (these are the same resource-valuable materials, that we importing). The reason is the low level of separate garbage collection, insufficient coverage of settlements by the system of separate collection, which determines the import, as well as the growth of the number of landfills.

Regional authorities in the direction of solid waste management should focus not only on the organization of collection, removal and disposal. The interest should be broader - the interest in creating a value chain, extending the life cycle of resources, its reproduction in new products. This will create additional jobs and encouraging new entrepreneurial initiatives.

Key words: import, waste, garbage, region, separate collection.

\section{Дзюбинская О.В., Дзюбинский А.В., Голодюк Г.И. ИМПОРТ ОТХОДОВ В УКРАИНЕ: ПРОБЛЕМА ИЛИ ПЕРСПЕКТИВЫ}

В статье рассмотрено ситуацию в сфере переработки твердых бытовых отходов (ТБО). Отмечается, что, несмотря на огромные ежегодные дополнительные объемы мусора на полигонах, украинские перерабатывающие предприятия вынуждены импортировать сырье. Вывод из этой ситуации один: наши ТБО низкого качества и не могут быть полноценно использованы в переработке. То есть импорт вынужденный. Единственным выходом из ситуации мы видим в как можно большем охвате регионов Украины раздельным сбором твердых бытовых отходов.

Ключевые слова: импорт, отходы, мусор, регион, раздельный сбор.

\section{Постановка проблеми у загальному вигляді та їі зв'язок 3 важливими науковими та практичними}


Економічні науки: збірник наукових праџь Луцького національного технічного університету. Серія "Регіональна економіка". Випуск 18 (71). Редкол.: відп. ред. д.е.н., професор Л.Л. Ковальська. Луиьк: ІВВ Луиького НТУ, 2021. 278 с.

завданнями. Переробка твердих побутових відходів - досить складний процес, який потребує не тільки значних фінансових вкладень, але й бажання нею займатися.

Прикладом раціонального налагодження роботи 3 відходами може слугувати Швеція, де не тільки майже повністю перероблюється власне сміття, але й здійснюється імпорт відходів. Виявляється, переробка може бути бізнесом, а тонни відходів на українських полігонах та сміттєзвалищах - дешевим ресурсом. Разом з тим сьогоднішня енергетична криза в Європі має дати поштовх розвитку сектору поводження 3 твердими побутовими відходами 3 огляду на можливість створення додаткових джерел енергії, а дослідження у цьому сегменті стають особливо актуальними.

Аналіз останніх досліджень, у яких започатковано вирішення проблеми. В сьогоднішніх умовах розвитку господарювання виникає потреба у пошуку оптимальних шляхів використання ресурсів та їх збереженню. Цього можна досягнути за рахунок зменшення обсягів утворення відходів i збільшення обсягів їх переробки та повторного використання на основі інноваційних технологій та виробництв.

Проблема ресурсозбереження розглядаються в працях I. Сотник, Л. Мельника, Л. Мусіної, С. Скокова, Т. Кваші; дослідження стану поводження 3 твердими побутовими відходами відображено в роботах О. Надраги, М. Щурика, А. Костюк, Є. Крикавського та О. Шандрівської.

Цілі статті полягають в оцінці перспектив розвитку сфери переробки твердих побутових відходів в Україні.

Виклад основного матеріалу дослідження 3 повним обгрунтуванням отриманих наукових результатів. Як не дивно це звучить, але вітчизняним підприємствам 3 переробки твердих побутових відходів не вистачає власної сировини (насамперед картонно-паперовій, склопереробній та підприємствам, що переробляють полімери і пластик). I це при тому, що мільйони тонн непереробленого сміття створюють, та створюватимуть в майбутньому, величезні проблеми українцям. Однією з головних причин такого стану справ фахівці вважають 
Економічні науки: збірник наукових праџь Луцького національного технічного університету. Серія "Регіональна економіка". Випуск 18 (71). Редкол.: відп. ред. д.е.н., професор Л.Л. Ковальська. Луиьк: ІВВ Луцького НТУ, 2021. 278 с.

відсутність належної інституційної підтримки роздільного збору сміття, що призводить до того, що українські відходи, в переважній своїй більшості, неякісні та непридатні для використання у переробці. На фоні такої ситуації виникає можливість прирівняти нас до скандинавів, поляків чи чехів та константувати, що ми також $є$ імпортером відходів (лише за 5 місяців 2021 року на імпорт сировини для переробних заводів Україна витратила близько 50 млн дол.). Тільки причини нашого імпорту інші. На звалищах перебувають тонни цінних відходів, $40 \%$ я яких - це тверді побутові відходи (ТПВ). За різними оцінками відсутність належної роботи по переробці відходів призводить до втрат від 5 млрд грн щороку.

Показовим прикладом того як сортування сміття впливає на економічний потенціал підприємства 3 переробки може слугувати Рівненський сміттєпереробний завод. У розвиток підприємства було вкладено 7 млн євро. На сьогодні воно функціонує на половину своєї потужності. В усьому винна відсутність якісної сировини: вологість відходів, що пропонуються підприємству становить 40 \% при гранично допустимих 20-и. Як наслідок калорійність палива, що виробляється заводом не відповідає стандарту. Вирішення проблеми - імпорт сировини.

За даними Міністерства розвитку громад та територій в нашій країні функціонує підприємств: 17 - переробляють папір; 39 - полімери; 19 - працюють $з$ ПЕТФ-сировиною та 16 займаються переробкою скла. Кожного року на ці заводи постачається 700 тис. т паперу, 120 тис. т пластмаси, 50 тис. т ПЕТ-пляшок, 460 тис. т скла. Функціонування підприємств суттєво залежить від рівня організації роздільного збору ТПВ, існування сортувальних ліній на сміттєзвалищах та пунктів приймання відходів. Стан існуючої системи збору ТПВ не сприяє максимальній завантажуваності виробничих потужностей переробних заводів. Як наслідок, ми змушені імпортувати. Результат вражає. Ми завозимо щороку $30 \%$ від потреби у макулатурі та приблизно 20 \% бою скла, а потужності 3 переробки пластику задіяні на $50 \%$ навіть із урахуванням 
Економічні науки: збірник наукових прачь Луиького національного технічного університету. Серія "Регіональна економіка". Випуск 18 (71). Редкол.: відп. ред. д.е.н., професор Л.Л. Ковальська. Луиьк: ІВВ Луцького НТУ, 2021. 278 с.

імпорту. Чи є така ситуаціє стимулом для інвестування в переробну сферу? Відповідь однозначна - ні.

Які ж саме відходи ми імпортуємо найбільше і чи можливо, в найближчій перспективі, якось вплинути на ситуацію? В таблиці 1[1] подано обсяги експортно-імпортних операцій у 2021 році.

Таблиця 1

Експорт та імпорт окремих видів ТПВ в Україні за 5 місяців 2021 року

\begin{tabular}{|l|c|c|c|c|}
\hline \multirow{2}{*}{ Вид відходів } & \multicolumn{2}{|c|}{ Експорт } & \multicolumn{2}{c|}{ Імпорт } \\
\cline { 2 - 5 } & тонн & млн грн & тонн & млн грн \\
\hline Макулатура & 6777 & 56 & 134217 & 950,53 \\
\hline Пластмаси & 1568 & 10 & 21939 & 229,19 \\
\hline Скло & 538 & 1,6 & 7058 & 9,76 \\
\hline
\end{tabular}

В Україні нагромаджується близько 1,5 млн тонн макулатури щороку при потребі 1 млн тонн. Схожа ситуація зі склом та пластиком. I знову приходиться констатувати, що більшість наших відходів неможливо переробити. В таблиці 2 [1] представлено географію країн, 3 яких ми імпортуємо відходи.

Таблиця 2

Географія імпорту ТПВ (5 місяців 2021 року)

\begin{tabular}{|l|c|c|c|c|c|c|}
\hline \multirow{3}{*}{ Країна } & \multicolumn{7}{|c|}{ Вид відходів } \\
\cline { 2 - 7 } & \multicolumn{2}{|c|}{ макулатура } & \multicolumn{2}{c|}{ пластмаса } & \multicolumn{2}{c|}{ скло } \\
\cline { 2 - 8 } & тонн & млн грн & тонн & млн грн & тонн & $\begin{array}{c}\text { млн } \\
\text { грн }\end{array}$ \\
\hline Польща & 66469 & 496,8 & 4221 & 4541 & - & - \\
\hline Словаччина & 23299 & 169,7 & 11,44 & 5,73 & - & - \\
\hline Румунія & 16225 & 103,25 & 19 & 0,17 & - & - \\
\hline Угорщина & 8780 & 53,53 & 362 & 1,77 & - & - \\
\hline Молдова & 7874 & 42,19 & - & - & - & - \\
\hline Латвія & 4145 & 25,79 & - & - & 1,261 & 1,36 \\
\hline Чехія & 3625 & 29,5 & - & - & - & - \\
\hline Росія & 2123 & 17,85 & 57 & 0,27 & - & - \\
\hline Білорусь & 681 & 3,98 & 2381 & 33,25 & 5,796 & 8,32 \\
\hline Чехія & - & - & 499 & 4,39 & - & - \\
\hline Болгарія & - & - & 39 & 0,29 & - & - \\
\hline Естонія & - & - & 22 & 0,5 & - & - \\
\hline
\end{tabular}


Економічні науки: збірник наукових праџь Луцького національного технічного університету. Серія “Регіональна економіка". Випуск 18 (71). Редкол.: відп. ред. д.е.н., професор Л.Л. Ковальська. Луиьк: ІВВ Луиького НТУ, 2021. 278 с.

Висновок 3 наведених вище даних єдиний - необхідно змінювати підходи у поводженні 3 твердими побутовими відходами.

Координувати сферу роздільного збору сміття та подальшого його використання належить до повноважень місцевих органів влади, що прописано Законом України «Про житлово-комунальні послуги» [2]. 301.05 .2019 р. місцева влада отримала більші повноваження стосовно переробки чи захоронення ТПВ, а також запровадження тарифів на поводження зі сміттям. Тобто можна говорити про формування регіональної політики поводження з ТПВ, де одну 3 головних ролей мають відігравати власники відходів. Вони повинні залучатися до процесу роздільного збору. Усі важливі моменти щодо сортування та логістики відходів повинні регламентуватися договором між надавачем послуг та їх власником. Перший має технологічно забезпечити вивіз вмісту контейнерів для роздільного збирання ТПВ, не змішуючи їх. В угодах можна розділяти види відходів, що збиратимуться.

На даний час найбільшого охоплення населених пунктів роздільним збором сміття набуло у Закарпатській області - від $15,9 \%$ у 2016 р. до 29,6 \% у 2018 р. (рисунок 1.1.).

Позитивна тенденція в регіоні дещо знизилася в 2019 р., коли кількість населених пунктів, охоплених роздільним збором ТПВ знизилася на кілька десятків. Високою, порівняно з іншими регіонами, $\epsilon$ частка роздільного збору відходів населених пунктів у Волинській, Тернопільській, Чернівецькій та Харківській областях. В цих регіонах в останні роки відзначається незначне зростання частки населених пунктів, охоплених роздільним збором сміття.

Не спостерігається ріст у Житомирській та Дніпропетровській областях. У 2019 р. відмічається скорочення питомої ваги охоплення роздільним збиранням ТПВ у ІваноФранківській, Київській, Луганській областях. У Західному макрорегіоні, порівнюючи 3 іншими, питома вага охоплення роздільним збором сміття є найвищою. У 2019 р. в загальному по Україні роздільний збір відходів був організований у майже 
Економічні науки: збірник наукових прачь Луиького національного технічного університету. Серія "Регіональна економіка". Випуск 18 (71). Редкол.: відп. ред. д.е.н., професор Л.Л. Ковальська. Луцьк: ІВВ Луцького НТУ, 2021. 278 с.

півтори тисячі населених пунктах, в кількісному значені на $24 \%$ більше (або 281), ніж у 2018 р. У 2019 р., у порівнянні з 2018 р., охоплення роздільним збором відходів найбільше виросла у Волинській області (на 77 населених пунктів). В ряді регіонів цей ріст склав від 5 до 45. Зокрема, у Чернігівській області на 5, Кіровоградській на 8, Херсонській на 10, Одеській на 11 , Полтавській на 13, Харківській на 25, Рівненській та Донецькій на 32, Сумській на 37, Тернопільській на 42, Львівській на 44, Вінницькій на 45.

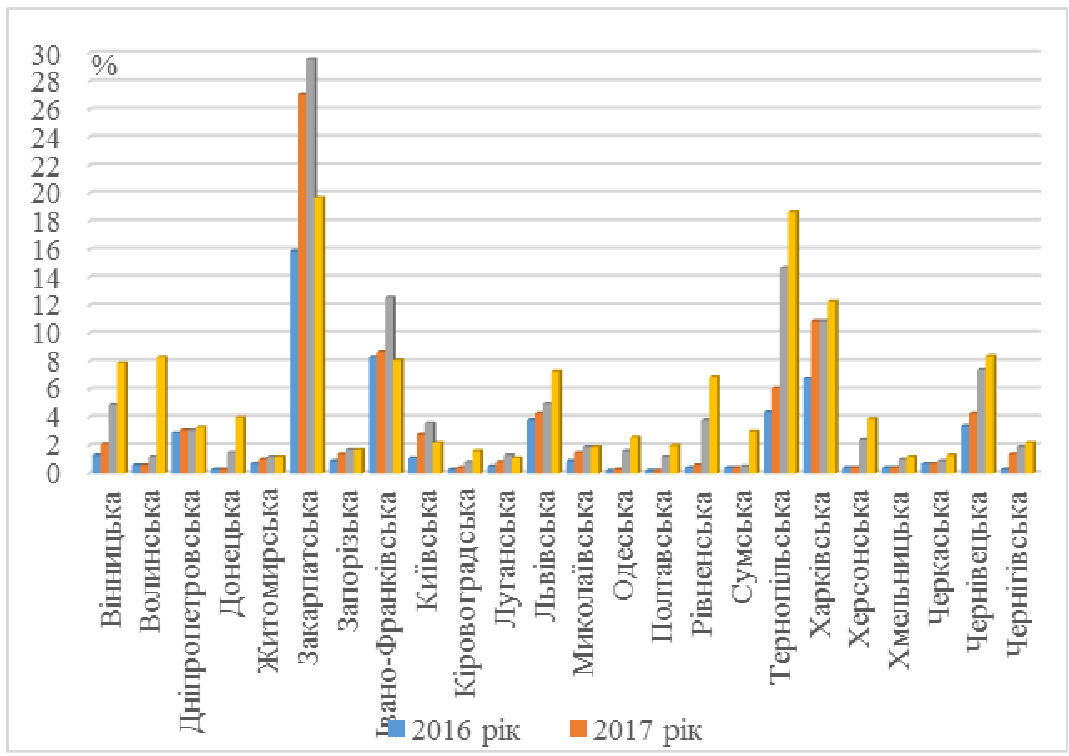

Рис. 1. Динаміка частки охоплення роздільним збором ТПВ населених пунктів у регіонах

Головним результатом використання роздільного збору ТПВ є одержання ресурсоцінних компонентів. Роздільний збір сміття без організації якісних та кількісних параметрів не дає змоги отримати оптимальний вихід компонентів із обсягу отриманих ТПВ. Кількісні - це формування тарного господарства. Якісні - визначаються технологією збору сміття. 
Економічні науки: збірник наукових прачь Луиького національного технічного університету. Серія "Регіональна економіка". Випуск 18 (71). Редкол.: відп. ред. д.е.н., професор Л.Л. Ковальська. Луиьк: ІВВ Луцького НТУ, 2021. 278 с.

Вони є базою для розробки регіональних програм поведінки 3 ТПВ. Технологічні схеми обираються у відповідності до Методики роздільного збирання побутових відходів [3].

Для встановлення потенціалу зібраних цінних компонентів відходів, важливо також володіти інформацією про морфологічний склад ТПВ. Він відрізняється не тільки в розрізі регіонів, але й залежить від природних факторів, наприклад пори року. Через це морфологічна структура сміття має визначатися періодично.

За допомогою експрес-аналізу деяких міських схем санітарного очищення та програм збирання ТПВ, регіональних програм поводження зі сміттям, стратегій управління ТПВ [4-5], було встановлено, що, в середньому, органіка складає $38 \%$ у загальному обсязі побутових відходів регіонів (діапазон від 14 до $49 \%$ ), відходи картону та паперу - 15,6 \% (діапазон - 1,2$35 \%$ ), скло - 10,7 \% (діапазон 4-24\%), частка пластику становить приблизно 10,5\% (від $3 \%$ до 19,6 \%), будівельні відходи займають нішу у $5 \%$ (діапазон 4-6\%), деревина - 4,5\% (діапазон 0,3-14\%), текстиль - 4,2 \% (діапазон 0,1-8\%), метал $4 \%$ (діапазон 1-11\%), а гума та шкіра - 2 \% (діапазон 0,5-5\%). У фокусі дослідження були наступні регіони: міста Кіровоград, Черкаси, Львів, Хмельницький, Івано-Франківськ, а також Донецька, Вінницька, Одеська, Полтавська, Закарпатська, Житомирська, Львівська області. Оцінивши склад відходів легше планувати роботу по їх збору, логістики, переробки чи утилізації.

Висновки. Імпорт відходів в Україні носить вимушений характер. I хоча майже 40 відсотків вітчизняних відходів це папір, скло та полімери (саме ті ресурсоцінні матеріали, що ми імпортуємо), основною практикою поводження 3 ТПВ $\epsilon$ їх захоронення. Причина - низький рівень роздільного збору сміття, недостатнє охоплення населених пунктів системою роздільного збору, що зумовлюють імпорт, а також ріст кількості сміттєвих полігонів.

Регіональні органи влади в напряму поводження 3 ТПВ головну увагу мають приділяти не лиш організації збору, 
Економічні науки: збірник наукових прачь Луиького національного технічного університету. Серія “Регіональна економіка". Випуск 18 (71). Редкол.: відп. ред. д.е.н., професор Л.Л. Ковальська. Луиьк: ІВВ Луцького НТУ, 2021. 278 с.

вивезення i захоронення. Інтерес повинен бути ширшим зацікавленість у створенні ланцюга вартості, подовженні життєвого циклу ресурсів, його відтворення у новій продукції. Це створить додаткові робочі місця та спонукатиме до появи нових підприємницьких ініціатив.

\section{Список бібліографічного опису}

1. Україна імпортує відходи з інших країн на мільярди. Чому так та як у нас працюе бізнес 3 переробки сміття? URL: https://www.epravda.com.ua/publications/2021/06/18/675131/

2. Про житлово-комунальні послуги: Закон України від 09.11.2017 р. № 2189-VIII. Дата оновлення: 02.04.2020. Відомості Верховної Ради Украӥни. 2018. № 1. C. 1. URL: https://zakon.rada.gov.ua/laws/show/2189-19.

3. Методика роздільного збирання побутових відходів: Наказ Міністерства регіонального розвитку, будівництва та житлово-комунального господарства України від 01.08.2011 р. № 133. Дата оновлення: 28.01.2020. URL: https://zakon.rada.gov.ua/laws/show/z1157-11.

4. Схема санітарного очищення м. Луцьк Волинської області. Луцьк: Луцька міська рада, 2018. 230 c. URL: www.lutskrada.gov.ua > documents > download.

5. Матвєєв Ю.Б., Гелетуха Г.Г. Перспективи енергетичної утилізаціїтвердих побутових відходів в Україні. Аналітична записка БАУ. 2019. № 22. 48 c. URL: https://uabio.org/wp-content/uploads/2020/01/positionpaper-uabio-22-ua.pdf

\section{References}

1. Ukraine imports billions from other countries. Why and how does our garbage recycling business work? URL: https://www.epravda.com.ua/publications/2021/06/18/675131/ [in Ukrainian].

2. Law of Ukraine on housing and communal services № 2189-VIII. (2017, November 9). Update (2020, April 2). Vidomosti Verkhovnoyi Rady Ukrayiny, 1, 1. URL: https://zakon.rada.gov.ua/laws/show/2189-19 [in Ukrainian].

3. Methods of separate collection of household waste: Order of the Ministry of Regional Development, Construction and Housing and Communal Services of Ukraine № 133 (2011, August 1). Update (2020, January 28). URL: https://zakon.rada.gov.ua/laws/show/z1157-11 [in Ukrainian].

4. Scheme of sanitary cleaning of Lutsk, Volyn region. (2018). Lutsk: Lutsk City Council. URL: www.lutskrada.gov.ua > documents > download. [in Ukrainian].

5. Matvyeyev Yu.B., Heletukha H.H. (2019). Prospects for energy utilization of solid waste in Ukraine. Analitychna zapyska BAU, 5. URL: https://uabio.org/wp-content/uploads/2020/01/position-paper-uabio-22-ua.pdf [in Ukrainian].

DOI: $\underline{\text { https://doi.org/10.36910/2707-6296-2021-18(71)-4 }}$ 